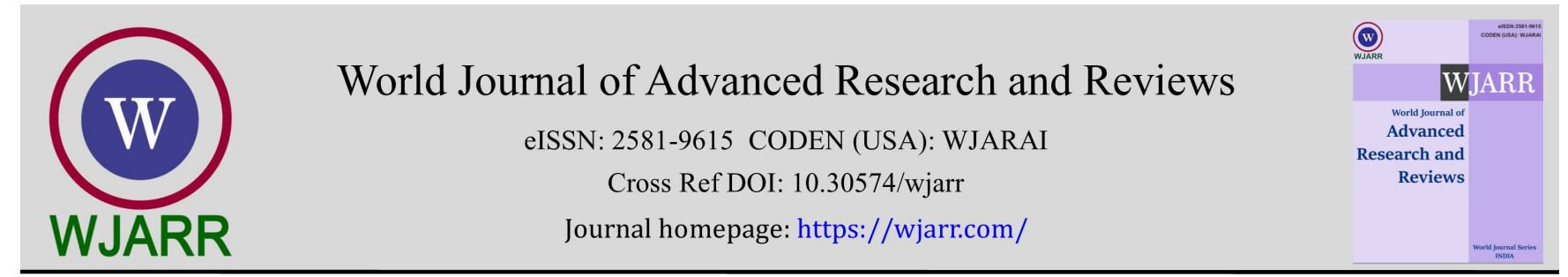

(REVIEW ARTICLE)

Check for updates

\title{
Health care of Brazilian indigenous peoples: Post-implementation of the National Indigenous Health Policy
}

Flávia Carvalho dos Santos Batista 1, Firmina Hermelinda Saldanha Albuquerque ${ }^{2,}{ }^{*}$, Karla Maria Carneiro Rolim 3, Manoel Viana Xavier ${ }^{4}$, Mirian Calíope Dantas Pinheiro ${ }^{3}$, Henriqueta Ilda Verganista Martins Fernandes ${ }^{5}$ and Mirna Albuquerque Frota ${ }^{3}$

1 Facult PROMINAS. Manaus, Amazonas, Brazil.

${ }^{2}$ Manaus School of Nursing, Federal University of Amazonas. Manaus, Amazonas, Brazil.

${ }^{3}$ University of Fortaleza. Fortaleza, Ceará, Brazil.

${ }^{4}$ Autonomous University of Asunción, Asunción-Paragual.

${ }^{5}$ Nursing School of Porto. Porto, Portugal.

World Journal of Advanced Research and Reviews, 2021, 10(01), 237-244

Publication history: Received on 15 March 2021; revised on 19 April 2021; accepted on 21 April 2021

Article DOI: https://doi.org/10.30574/wjarr.2021.10.1.0166

\begin{abstract}
The objective was to describe, through key points of indigenous health care, what has changed after the implementation of the National Health Care Policy for Indigenous Peoples. For this, the research method chosen was the literature review with a qualitative approach of the results. The studies that composed the sample were retrieved from the SciELO and PubMed databases, from May to August 2018. The results point to the deficiency of training of professionals of the Multidisciplinary Team of Indigenous Health (EMSI) in the context of interethnic relations; the need to define the functions of Indigenous Health Agents (IHA) within EMSI; the good acceptance by indigenous peoples and EMSI regarding biomedical and traditional indigenous treatments, respectively; in addition to the food deficiency of the Indigenous Health Care Information System. That said, there should be trainings in the scope of interethnic action for EMSI and IHA with clear definition of each one' roles within EMSI, especially the IHA.
\end{abstract}

Keywords: Indigenous Population; Public Policy; Indigenous Health Services

\section{Introduction}

The National Health Care Policy for Indigenous Peoples (PNASPI) emerged in 2002, from Ordinance no. 254 of January 31,2002 , as a result of claims presented by indigenous peoples initially at the I National Conference for the Protection of Indigenous Health and the II National Health Conference for Indigenous Peoples [1].

The PNASPI is based on the principles of the Unified Health System (UHS), aims to guarantee indigenous peoples access to comprehensive health care, covering and respecting social, cultural, geographical, historical and political diversity, as well as recognizing the medical effectiveness of the right of those peoples to their culture [1].

Given the time elapsed since the implementation of the PNASPI, this research is justified by the concern to find what improvements occurred in the health care of Brazilian indigenous peoples after the implementation of the National Health Care Policy for Indigenous Peoples? Aiming to describe, through key points, what has changed in the health care of indigenous peoples, since the implementation of PNASPI.

\footnotetext{
* Corresponding author: Firmina Hermelinda Saldanha Albuquerque

Manaus School of Nursing, Federal University of Amazonas. Manaus, Amazonas, Brazil.
}

Copyright $(2021$ Author(s) retain the copyright of this article. This article is published under the terms of the Creative Commons Attribution Liscense 4.0. 


\section{Methods}

This is an integrative literature review, which aims to synthesize results obtained in studies on a theme or question, in a systematic, orderly and comprehensive manner [2]. Considered indispensable in the health area, since it directs the practice based on scientific knowledge, through compiled research in relation to a given subject [2].

This research followed the six steps: identification of the theme and elaboration of the research question; definition of inclusion and exclusion criteria; definition of the information to be extracted from the selected studies; evaluation of the studies included; interpretation of the results and presentation of the synthesis of knowledge [3]. To this end, a search of the studies was carried out at the SciELO and PubMed databases, from May to August 2018.

After identifying the articles and excluding those repeated in different databases, they were analyzed, starting with the reading of the titles, followed by the reading of the abstracts and, later, of the complete texts. The evaluation and selection of the articles were made according to the inclusion and exclusion criteria.

The inclusion criteria were complete studies, available free of charge and electronically, in the SciELO and PubMEd databases, original articles, literature review and experience report. Exclusion criteria: articles published outside the timeline that corresponded to the period from 2002 to 2018. The selected articles were analyzed through qualitative synthesis in order to characterize the study conducted.

The descriptors used followed the description of the terms DeCS - Health Sciences Descriptors, in the articles researched in the SciElo platform, namely: "Saúde de populações indígenas", "política pública", "população indígena" and "serviços de saúde do indígena". In the articles researched at the PubMEd platform, the description of Mesh - Medical Subject Headingswas used, with the following descriptors: "Health Services, Indigenous", "Public Policy" "Brazil". The descriptors were combined using the Boolean operators "AND" and "OR" in both cases.

At the SciELO database, the search paths were divided into two searches. In the first search, the research path was: (saúde de populações indígenas) AND (política pública). In the next search, the research path was: (saúde de populações indígenas) AND (população indígena).

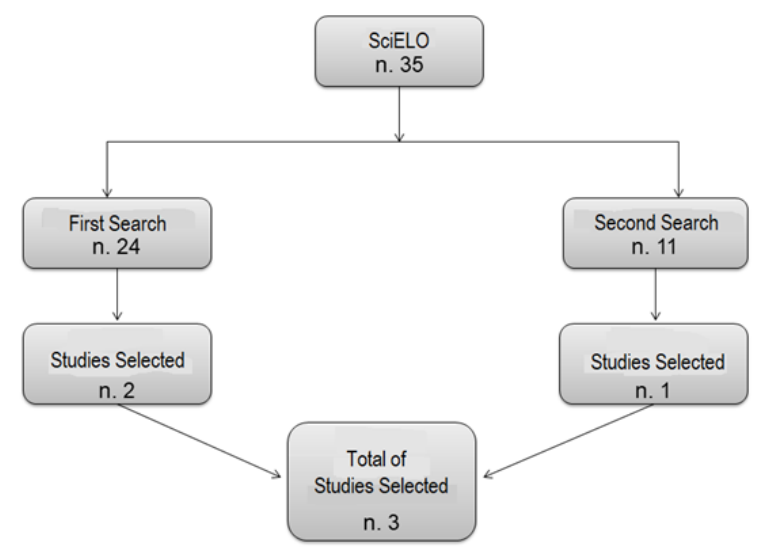

Figure 1 Flowchart of the search at SciELO database

At the PubMed Database, we searched for articles with the descriptors Health Services, Indigenous, Brazil, Public Policy, using the Boolean operator AND. All descriptors used for research in this database were previously searched at MeSH.

The research path used was: (Health Services, Indigenous) AND Brazil AND Public Policy. Returning 22 studies, then marking the search filter of the database itself: Free full text, 18 articles remained, of which 6 articles were selected.

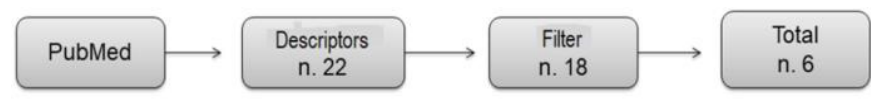

Figure 2 Flowchart of the search at PubMed database 
In total, nine studies were selected from both databases for later discussion of the results found based on other studies, allowing elaborating the final text.

The results will be presented and discussed according to eight key points found in the articles in the sample of this research, namely: Interethnic Relationship of multidisciplinary Teams of Indigenous Health - EMSI; Indigenous Health Agent - IHA; Sanitation in villages; Access of indigenous peoples to Health Services of the UHS; Indigenous' adherence to biomedical treatments; Physical space and transportation of indigenous peoples (Casa de Saúde Indígena - CASAI and Postos dos Polos Base); Performance of Non-Governmental Organizations (NGOs) as service providers and Data Exposure on Indigenous Health.

\section{Results and discussion}

Table 1 Characteristics of the studies selected.

\begin{tabular}{|c|c|c|c|c|c|c|}
\hline $\begin{array}{l}\mathbf{N} \\
\underline{\mathbf{o}}\end{array}$ & $\begin{array}{l}\text { Indexin } \\
\text { g base }\end{array}$ & Journal & Title & Objective & Method & Year \\
\hline 1 & SciELO & $\begin{array}{l}\text { Interface: } \\
\text { Comunicaç } \\
\text { ão saúde e } \\
\text { educação }\end{array}$ & $\begin{array}{l}\text { PET-Health/Networks for } \\
\text { indigenous people: beyond } \\
\text { the university, a reflection } \\
\text { on knowledge and health } \\
\text { practices [4] }\end{array}$ & $\begin{array}{l}\text { To carry out a situational } \\
\text { mapping of the care network } \\
\text { that meets these people in the } \\
\text { municipality, as well as identify } \\
\text { their challenges, potentialities } \\
\text { and intersections between the } \\
\text { indigenous policy and the } \\
\text { Unified Health System (UHS). }\end{array}$ & $\begin{array}{l}\text { Experience } \\
\text { report }\end{array}$ & 2015 \\
\hline 2 & SciELO & $\begin{array}{l}\text { Reports in } \\
\text { Public } \\
\text { Health }\end{array}$ & $\begin{array}{l}\text { The contribution of } \\
\text { indigenous community } \\
\text { health workers to special } \\
\text { healthcare for Brazilian } \\
\text { indigenous peoples [5] }\end{array}$ & $\begin{array}{l}\text { To analyze the role of IHA } \\
\text { through its incorporation, } \\
\text { training and participation in } \\
\text { health teams in different } \\
\text { contexts in the country. }\end{array}$ & Review & 2012 \\
\hline 3 & SciELO & $\begin{array}{l}\text { Esc. Anna } \\
\text { Nery } \\
\text { Revista de } \\
\text { Enfermage } \\
\mathrm{m}\end{array}$ & $\begin{array}{l}\text { Life and health conditions } \\
\text { of elderly indigenous } \\
\text { Kaingang [6] }\end{array}$ & $\begin{array}{l}\text { To describe the living and } \\
\text { health conditions of Kaingang } \\
\text { elderly people from Faxinal } \\
\text { Indigenous Land - Paraná. }\end{array}$ & $\begin{array}{l}\text { Qualitative } \\
\text { study, } \\
\text { supported } \\
\text { by the } \\
\text { ethinographi } \\
\text { c method }\end{array}$ & 2015 \\
\hline 4 & PubMed & $\begin{array}{l}\text { Reports in } \\
\text { Public } \\
\text { Health }\end{array}$ & $\begin{array}{l}\text { Indigenous peoples' access } \\
\text { to health services in } \\
\text { Cuiabá, Mato Grosso State, } \\
\text { Brazil [7] }\end{array}$ & $\begin{array}{l}\text { To assess the access of } \\
\text { indigenous users to health } \\
\text { services of medium and high } \\
\text { complexity in the Municipality } \\
\text { of Cuiabá, MT, Brazil, from } \\
\text { CASAI. }\end{array}$ & $\begin{array}{l}\text { Single, } \\
\text { qualitative } \\
\text { case study. }\end{array}$ & 2017 \\
\hline 5 & Pubmed & $\begin{array}{l}\text { Ciência \& } \\
\text { Saúde } \\
\text { Coletiva }\end{array}$ & $\begin{array}{l}\text { The differentiated care } \\
\text { model in the Special } \\
\text { Indigenous Health } \\
\text { Districts: reflections based } \\
\text { on Alto Rio Negro in } \\
\text { Amazonia State, Brazil [8] }\end{array}$ & $\begin{array}{l}\text { To analyze the implementation } \\
\text { of the care model of the } \\
\text { National Indigenous Health } \\
\text { Policy (PNASPI) in the Alto Rio } \\
\text { Negro indigenous special health } \\
\text { district, in the light of the } \\
\text { differentiated care guideline. }\end{array}$ & $\begin{array}{l}\text { Qualitative } \\
\text { research }\end{array}$ & 2015 \\
\hline 6 & Pubmed & $\begin{array}{l}\text { Reports in } \\
\text { Public } \\
\text { Health }\end{array}$ & $\begin{array}{l}\text { Politics and inter- } \\
\text { medicality in the Upper } \\
\text { Xingu: from model to } \\
\text { practice in indigenous } \\
\text { health care [9] }\end{array}$ & $\begin{array}{l}\text { To understand how it is } \\
\text { possible to reconcile universal } \\
\text { access to health goods and } \\
\text { services with care that } \\
\text { guarantees differentiation, }\end{array}$ & Case study & 2011 \\
\hline
\end{tabular}




\begin{tabular}{|c|c|c|c|c|c|c|}
\hline $\begin{array}{l}\mathbf{N} \\
\underline{\mathbf{o}}\end{array}$ & $\begin{array}{l}\text { Indexin } \\
\text { g base }\end{array}$ & Journal & Title & Objective & Method & Year \\
\hline & & & & $\begin{array}{l}\text { without interfering, however, in } \\
\text { the quality of services offered. }\end{array}$ & & \\
\hline 7 & PubMEd & $\begin{array}{l}\text { Reports in } \\
\text { Public } \\
\text { Health }\end{array}$ & $\begin{array}{l}\text { Indigenous organizations } \\
\text { and health district } \\
\text { apportionment: the gap } \\
\text { between seeing and } \\
\text { believing in health policies } \\
{[10]}\end{array}$ & $\begin{array}{l}\text { To analyze ethnopolitical, } \\
\text { ethical and sanitary } \\
\text { repercussions on the practices } \\
\text { of indigenous organizations, in } \\
\text { partnership with the Ministry } \\
\text { of Health, linked to the process } \\
\text { of implantation of DSEI in the } \\
\text { State of Amazonas. }\end{array}$ & $\begin{array}{l}\text { Documentar } \\
\text { y and } \\
\text { observation } \\
\text { al research. }\end{array}$ & 2005 \\
\hline 8 & PubMed & $\begin{array}{l}\text { Reports in } \\
\text { Public } \\
\text { Health }\end{array}$ & $\begin{array}{l}\text { The Sanumá-Yanomami } \\
\text { medical system and } \\
\text { indigenous peoples' health } \\
\text { policy in Brazil [11] }\end{array}$ & $\begin{array}{l}\text { To discuss how the Sanumá } \\
\text { indigenous people, a subgroup } \\
\text { of the Yanomami linguistic } \\
\text { family, act and relate to the } \\
\text { indigenous health care policy. }\end{array}$ & $\begin{array}{l}\text { Field study } \\
\text { based on the } \\
\text { ethnographi } \\
\text { c method }\end{array}$ & 2015 \\
\hline 9 & PubMed & $\begin{array}{l}\text { Health and } \\
\text { Human } \\
\text { Rights } \\
\text { Journal }\end{array}$ & $\begin{array}{l}\text { Indigenous Child Health in } \\
\text { Brazil: The Evaluation of } \\
\text { Impacts as a Human Rights } \\
\text { Issue [12] }\end{array}$ & $\begin{array}{l}\text { To evaluate interventions that } \\
\text { address the health of } \\
\text { indigenous children in Brazil, } \\
\text { from those that explicitly } \\
\text { address the health of } \\
\text { indigenous children, such as the } \\
\text { immunization program for } \\
\text { indigenous peoples, as well as } \\
\text { more generalized programs, } \\
\text { including the focus on } \\
\text { indigenous children, such as } \\
\text { Integrated Childhood Disease } \\
\text { Management. }\end{array}$ & $\begin{array}{l}\text { Literature } \\
\text { review }\end{array}$ & 2016 \\
\hline
\end{tabular}

The evolution of the analyzed studies went from 2005 to 2017, peaking in 2015, concentrating 4 articles. The journal with the highest number of articles selected was the Reports in Public Health, with 5 publications.

Interethnic relationship of the Multidisciplinary Indigenous Health Team - EMSI.

Of the 9 articles selected for this study, 4 addressed the interethnic relationship of multidisciplinary health professionals as an evaluative point in their research [4-5,7,9] among which, 3 pointed out some level of unpreparedness through these teams, while only one of the articles reported the preparation of professionals in this context.

In the indigenous people's perspective, EMSI is unprepared and needs training to be able to understand the importance of interethnic relationship, concomitantly biomedical and traditional treatment, as well as the disease-health process in the conception of its target audience. This lack of knowledge of EMSI translates into purely technical care, which hinders the population's treatment support [11].

\subsection{Indigenous Health Agent - IHA}

On this point, 3 of the articles addressed the participation of the IHA in the PNSI as a link between EMSI and the indigenous population [5,8-9], reporting their training based on the biomedical model, with Diehl et al [7]. reporting the difficulty in training those professionals due to the high turnover of EMSI, who are responsible for performing such trainings. Novo [9] reports the expectation controversy between EMSI and the IHA, where the former expect the latter to base their work on the biomedical perspective, while the latter expect the former to go beyond the biomedical perspective and practice inter-ethics. Pontes et al. [8], in turn, point out that, despite basing the training of IHA on biomedical vision, EMSI sees the role of IHA as purely operational support, and not as an active part of the team. 
Guimarães [11] compares in her study the IHA of two subgroups of the Yanomami linguistic family: the Sanumá and the Yekuana. The Sanumá points out as being resistant to fidelity to the biomedical treatment system, contrary to the expectation of EMSI, which decreased its functions and autonomy, while the Yekuana assisted EMSI and served as translators, which "pleased" EMSI and consequently increased its functions and autonomy.

Diehl et al. [5] point out in their review that IHAs are sometimes seen as subordinates by the other members of EMSI, because among this team is the IHA who has less knowledge (for lack of better expression). And one of the factors that corroborates this situation is high turnover of the other members of EMSI, because they are responsible for the training of the IHA. This ends up limiting the role of IHA as merely bureaucratic (in filling out forms) and supportive (in the distribution of medication and in the warnings to be given to communities).

\subsection{Sanitation in villages}

Borghi and Carreira [6] demonstrate the sanitary reality of the Faxinal Indigenous Land (TIF) - Paraná, reporting the change in traditional housing from a program of the state government that built masonry houses and ceramic tile roofs. The study also reports the construction of septic toilets and tanks, also by the state government, as well as piped water, highlights the lack of selective collection, and the disposal of garbage to burn or be buried. It also mentions that IHAs are responsible for the maintenance of water distributed in the pipes.

Rios et al. [13] explain in their study the sanitary conditions in the indigenous area Iauaretê - São Gabriel da Cachoeira/AM, describing the lack of basic sanitation, where human feces in peridomiciliary regions, near wells and springs can be found. This study performed laboratory analysis on water samples used for human consumption collected in the main villages in the Iauaretê indigenous area, finding $89.2 \%$ to $100 \%$ of the samples collected with contamination by thermotolerant coliforms. The disposal of garbage was also a research issue in this study, pointing out the incorrect disposal (burning, throwing in rivers or stream, ravines, landfill, etc.) and the lack of selective collection, also highlighting the inadequate disposal of hospital waste, deposited in an open dump, which causes serious risks to the health of this population.

\subsection{Access of indigenous peoples to Health Services of the UHS}

Cuervo et al. [4] point out that, when indigenous peoples need to use the UHS, they see themselves as privileges over UHS users in general, who sometimes become hostile, in addition to UHS professionals' common prejudice and fear when they come across indigenous patients, which further worsens the situation. Gomes and Esperidião [7] point out the regulation of indigenous peoples who need medium and high complexity care as partially satisfactory, having as one of the greatest barriers the lack of standardization in the reference and counter-reference flow. It is worth mentioning that a study at CASAI of Santarém/PA with several ethnic groups that used that institution demonstrated the dissatisfaction of indigenous peoples with the long wait to obtain care in the specialized network of the UHS (secondary and tertiary), schedule exams and financial difficulties to perform examinations and private consultations, as well as to buy medication [14].

\subsection{Indigenous' adherence to biomedical treatments}

Pontes et al. [8] and Guimarães [11] point out in their studies a good acceptance by indigenous peoples and EMSI in the joint use of traditional indigenous and biomedical treatments. Guimarães [11] makes it very clear that the option of biomedical treatment by indigenous leaders is well accepted, and it is up to each indigenous to opt for the type of treatment or concomitant treatment.

Garnelo and Sampaio [15] corroborate this perspective in their study, which points to the growing demand for medicines and specialized health services as proof of the acceptance of biomedical treatment by indigenous peoples.

Guimarães [11], ratifies these studies emphasizing biomedical treatment as complementary to Shamanic treatment, and also stressing the freedom given to the indigenous to choose the therapeutic itinerary to be followed.

Pontes et al. [16] point out that, although for the Baniwa of the DSEI Alto Rio Negro "there is no conflict or contradiction in the use of biomedical therapy", they seek to solve their health problems primarily with traditional therapy.

\subsection{Physical space and transportation of indigenous peoples (Casa de Saúde Indígena - CASAI and Postos dos Polos Base)}

Gomes and Esperidião [7] together with Novo [9] bring as one of the problems of these studies the inadequacy of the physical spaces of health services (CASAI and Postos dos Polos Base), where the culture of each indigenous people was 
not taken into account when each of these establishments was designed. Gomes and Esperidião [7] report the precarious infrastructure of CASAI of Cuiabá/MT, while Novo [9] points to negligence with the culture of that population, causing the indigenous people themselves to "suit" CASAI of the Leonardo Base Pole, in the Upper Xingu, being sometimes named by EMSI professionals as vandals and "ingrates".

Silva et al. [14] demonstrate in their study the dissatisfaction on the part of the indigenous users of CASAI of Santarém with the precarious physical structure of the institution, and among the main complaints are overcrowding, inadequate ventilation of the place, as well as physical structure and lack of water in bathrooms, in addition to the diet offered by the institution that differs from that which the indigenous usually eat in their villages. There were also reports of dissatisfaction regarding the "mixture" between ethnic groups, that is, indigenous peoples do not feel comfortable sharing the same space with different ethnic groups.

For Pontes et al. [16], interviewed several indigenous peoples of the Baniwa ethnic group, belonging to the DSEI Alto Rio Negro/AM, asking them why the indigenous people did not like to go to the city. Complaints about the infrastructure of both CASAI of São Gabriel da Cachoeira/AM, which is the first reference, and CASAI Manaus/AM, which receives patients for specific consultations and treatments, as well as support to indigenous people in tertiary care, were obtained as response. Among the complaints are the lack of space, mixing of indigenous peoples with different ethnic groups, heat, water supply, among others.

\subsection{Performance of NGOs as service providers}

Garnelo and Sampaio [10] emphasize the participation of NGOs, which are no longer just activists supporting the indigenous cause, but are also health service providers. They also report that one of the key points for this change of performance was the high turnover of professionals and the interest of the indigenous people themselves in relation to this change, because they believed that such change was a shorter form or path to greater indigenous representation and the taking of indigenous self-responsibility.

For Garnelo and Sampaio [15], the government's decision to outsource the management and health services of the indigenous health subsystem is a way of exempting itself in a certain way from the constitutional responsibility that is implied.

An exception to what happened on the national scenario, in the Angra dos Reis/RJ Base-Pole, EMSI is composed of career employees, hired by the municipality of Angra dos Reis and employees hired under the Labor Law Consolidation (CLT) regime, however, with local re-contracting mechanisms between the city hall and the Municipal Council of Residents, paid with resources from the Ministry of Health, which favored the continuity of health actions and services provided to that population [17].

\subsection{Data Exposure on Indigenous Health}

Coates et al. [12] report and emphasize the existence of difficulties in presenting concrete data that point to the evolution of health coverage to indigenous peoples, especially those related to children, which, according to the authors, demonstrates that: "The precise formula has not yet been identified to better measure the impact of health policies on marginalized ethnic populations, such as indigenous children" [12:p.225].

They also expose the immunization of indigenous children as one of the priorities of PNASPI, besides pointing to the participatory and intercultural approach to indigenous peoples as a positive impact that corroborates the optimal vaccination coverage of this population.

From this perspective, Chaves et al. [17] detected in their study at the Angra dos Reis/RJ Base-Pole the difficulty in the flow of information from indigenous health data, with the main question being the large number of forms and their frequent modifications, in addition to the work overload, since the EMSI of that Base Pole needs to provide information on care provided to the National Information System, because the health unit has been registered in the UHS since 1995, and its incorporation into the health subsystem does not oblige it to provide such information also to the MIS (Mortality Information System).

Sousa et al. [18], confirm these statements and complement that one of the great difficulties of putting into practice the Indigenous Health Care Information System (SIASI) is the quality of the data collected, because the professionals who make up the EMSI feel disinterested in filling out the information contained in the forms, due to the large number of variables that for these professionals have little or no relevance in the practice of indigenous health care. This makes evident the need for EMSI training concerning SIASI feeding forms. 


\section{Conclusion}

Over a decade has passed since the implementation of PNASPI, and the doubts that arises is what has changed, what improvements have occurred? The response is of great importance, as it can serve as parameters for adaptations and future policies aimed at improving the health of the Indigenous Population.

This study pointed to worrying data regarding the relationship between EMSI and the population, because the deficiency of training of those teams in the inter-ethnic sphere generates barriers between interaction with indigenous peoples, which consequently reflects on the quality and effectiveness of indigenous health care.

Regarding the IHAs, the need to define their roles within the team was clear. The lack of continued training of those professionals by EMSI causes this professional to be underutilized in most of the cases, thus not fulfilling what the PNASPI recommends: that it his/she acting mainly as a link between EMSI and the indigenous population, in order to value the local culture.

On the other hand, this study demonstrates that respect for the traditional treatment of indigenous peoples towards the disease is well accepted most often by EMSI, as well as the biomedical treatment used by EMSI is also well adopted by indigenous peoples, and that most of the times they make concomitant use of both types of health care.

One of the points of extreme relevance among the findings of this research was the evident need for adequacy of the SIASI, since it is of great importance to measure the efficacy of the care provided to Indigenous Health, but, from what the study showed, it is underreported, because the number of forms is large and contains information that often might or might not be relevant for the professional in direct care to the indigenous patient, making the professional feel demotivated to seek and record that information.

For all this, one reinforces the need for training in the context of inter-ethnic action for EMSI and basic training for IHA on their attributions, role and clear definition of the activities to be performed within EMSI. As for the SIASI, it would be interesting to offer a simplification of the data obtained in the SIASI feeding forms, from a research directed to the professionals who feed this system, because they are the most indicated to report, from their inter-ethnic experience, what applies or not to indigenous peoples and that can serve as data to be compiled also within the National Information Systems of the UHS.

\section{Compliance with ethical standards}

\section{Acknowledgments}

We thank all who participated in the study.

\section{Disclosure of conflict of interest}

The authors declare that there is no conflict of interest.

\section{References}

[1] Brasil. Ministério da Saúde. Fundação Nacional de Saúde. Política Nacional de Atenção a Saúde dos Povos Indígenas. 2. ed. Brasília: Ministério da Saúde. 2002.

[2] Ercole FF, Melo LS, Alcoforado CLGC. Revisão integrativa versus revisão sistemática. Rev Min Enferm. 2014; 18(1): 9-11.

[3] Mendes KDS, Silveira RCCP, Galvão CM. Revisão integrativa: método de pesquisa para incorporação de evidências na saúde e na enfermagem. Texto \& Contexto Enferm. 2008; 17(4): 758-64.

[4] Cuervo MRM, Radke MB, Riegiel EM. PET - Redes de atenção à saúde indígena: Além dos muros da universidade, uma reflexão sobre saberes e práticas em saúde. Interface. 2015; 1(9): 953-63.

[5] Diehl EE, Langdon EJ, Dias-Scopel RP. Contribuição dos agentes indígenas de saúde na atenção diferenciada à saúde dos povos indígenas brasileiros. Cad Saúde Pública. 2012; 28(5): 819-31.

[6] Borghi AC, Carreira L. Condições de vida e saúde do idoso indígena Kaingang. Esc Anna Nery. 2015; 19(3): 5117. 
[7] Gomes SC, Esperidião MA. Acesso dos usuários indígenas aos serviços de saúde de Cuiabá, Mato Grosso, Brasil. Cad Saúde Pública. 2017; 33(5): e00132215.

[8] Pontes AL, Rego S, Garnelo L. O modelo de atenção diferenciada nos Distritos Sanitários Especiais Indígenas: reflexões a partir do Alto Rio Negro/AM, Brasil. Ciênc Saúde Coletiva. 2015; 20(10): 3199-210.

[9] Novo MP. Política e intermedicalidade no Alto Xingu: do modelo à prática de Atenção à saúde indígena. Cad Saúde Pública. 2011; 27(7): 1362-70.

[10] Garnelo L, Sampaio S. Organização indígena e distritalização sanitária: os riscos de "fazer ver" e "fazer crer" na política de saúde. Cad Saúde Pública. 2005; 21(4): 1217-23.

[11] Guimarães SMF. O sistema médico Sanumá-Yanomami e sua interação com as práticas biomédicas de atenção à saúde. Cad Saúde Pública. 2015; 22(10): 2148-56.

[12] Coates AR, Marchito SDP, Vitory B. Indigenous Child Health in Brazil: The Evalution of Impacts as a Human Rights Issue. Health Human Rights J. 2016; 18(1): 221-34.

[13] Rios L, Cutolo SA, Giatti LL, Castro M, Rocha AA, Toledo RF et al. Prevalência de parasitos intestinais e aspectos socioambientais em comunidade indígena no distrito de Iauaretê, Município de São Gabriel da Cachoeira (AM), Brasil. Saúde Soc. 2017; 16(2): 76-86.

[14] Silva DM, Nascimento EHS, Santos LA, Martins NVN, Sousa MT, Figueira MCS. Dificuldades enfrentadas pelos indígenas durante a permanência em uma casa de saúde indígena na região Amazônica/Brasil. Saúde Soc. 2016; 25(4): 920-9.

[15] Garnelo L, Sampaio S. Bases sócio-culturais do controle em saúde indígena. Problemas e questões da Região Norte do Brasil. Cad Saúde Pública. 2003; 19(1): 311-7.

[16] Pontes ALM, Garnelo L, Rego S. Reflexões sobre questões morais na relação de indígenas com os serviços de saúde. Rev Bioét. 2014; 22(2): 337-46.

[17] Chaves MBG, Cardoso AM, Almeida C. Implementação da política de saúde indígena no Polo-base Angra dos Reis, Rio de Janeiro, Brasil: entraves e perspectivas. Cad Saúde Pública. 2006; 22(2): 295-305.

[18] Sousa MC, Scatena JHG, Santos RV. O Sistema de informação da Atenção de Saúde Indígena (SIASI): criação, estrutura e funcionamento. Cad Saúde Pública. 2007; 23(4): 853-61. 